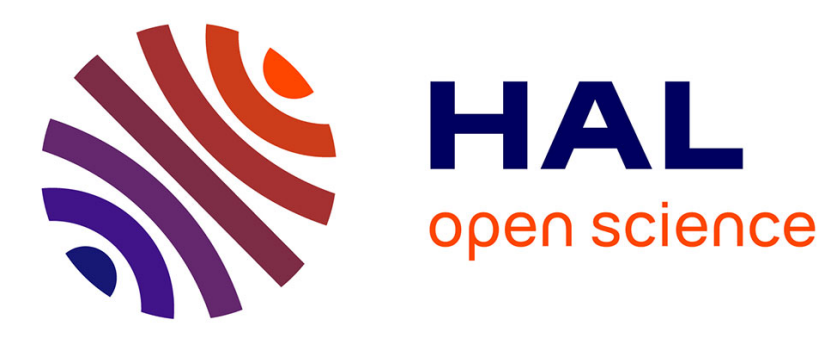

\title{
Peculiar tension wood structure in Laetia procera (Poepp.) Eichl. (Flacourtiaceae)
}

Julien Ruelle, Masato Yoshida, Bruno Clair, Bernard Thibaut

\section{To cite this version:}

Julien Ruelle, Masato Yoshida, Bruno Clair, Bernard Thibaut. Peculiar tension wood structure in Laetia procera (Poepp.) Eichl. (Flacourtiaceae). Trees - Structure and Function, 2007, 21 (3), pp.345-355. 10.1007/s00468-007-0128-0 . hal-00194923

\section{HAL Id: hal-00194923 \\ https://hal.science/hal-00194923}

Submitted on 7 Dec 2007

HAL is a multi-disciplinary open access archive for the deposit and dissemination of scientific research documents, whether they are published or not. The documents may come from teaching and research institutions in France or abroad, or from public or private research centers.
L'archive ouverte pluridisciplinaire HAL, est destinée au dépôt et à la diffusion de documents scientifiques de niveau recherche, publiés ou non, émanant des établissements d'enseignement et de recherche français ou étrangers, des laboratoires publics ou privés. 


\section{ORIGINAL ARTICLE}

Julien Ruelle $\cdot$ Masato Yoshida $\cdot$ Bruno Clair $\cdot$ Bernard Thibaut

Peculiar tension wood structure in Laetia procera (Poepp.) Eichl. (Flacourtiaceae)

J. Ruelle (Contact), B. Thibaut

UMR EcoFoG, Campus agronomique - BP 709, 97387 Kourou cedex, Guyane Française Tel. +594594320347; Fax +594594323281

e-mail: ruelle_j@kourou.cirad.fr

M. Yoshida

School of Bioagricultural Sciences, Nagoya University, Chikusa,

Nagoya 464-8601, Japan

B. Clair

Laboratoire de Mecanique et Genie Civil (LMGC)

UMR 5508, CNRS - Universite Montpellier 2

Place E. Bataillon, cc 048, 34095 Montpellier Cedex 5, France 


\section{ABSTRACT}

2 Tension wood of Laetia procera (Poepp.) Eichl. (Flacourtiaceae), a neo-tropical forest

3 species, shows a peculiar secondary wall structure, with an alternance of thick and thin

4 layers, while opposite wood of this species has a typical secondary wall structure

$5 \quad(\mathrm{~S} 1+\mathrm{S} 2+\mathrm{S} 3)$. Samples for the study of microstructural properties were collected upon

6 estimation of growth stresses in the living tree, in order to analyse correlation of the

7 former with the latter. Investigation using optical microscopy, scanning electron

8 microscopy and UV microspectrophotometry allowed the description of the anatomy,

9 ultra-structure and chemistry of this peculiar polylaminate secondary wall. In the thick

10 layers, cellulose microfibril angle is very low (i.e., microfibril orientation is close to fibre

11 axis) and cellulose microfibrils are well organised and parallel to each other. In the thin

12 layers, microfibrils (only observable in the inner layer) are less organised and are oriented

13 with a large angle relative to the axis of the cell. Thick layers are lightly lignified

14 although thin layers show a higher content of lignin, close to that of opposite wood

15 secondary wall. The more the wood was under tensile stress, the less the secondary wall

16 was lignified, and the lower the syringyl on guaiacyl lignin units ratio was. The innermost

17 layer of the secondary wall looks like a typical S3 layer with large microfibril angle and

18 lignin occurrence. The interest of this kind of structure for the understanding of stress

19 generation is discussed.

20

21 Keywords Tension wood - Tropical rainforest species - UV microspectrophotometry •

22 Scanning Electron Microscopy $\cdot$ Cellulose microfibril angle 
24 In order to restore their verticality after accidental leaning, to maintain the branch at a given angle or to change axis orientation to reach the canopy for better access to light trees are able to bend progressively their trunk or branches by a very active mechanical action driven by cambial activity (Sinnott 1952). This reorientation is associated with the formation of a peculiar type of wood, called reaction wood. In gymnosperm species, reaction wood is formed on the lower side of the tilted axis (compression wood), while in angiosperm species it is formed on the upper side (tension wood). Whatever the species considered, the process of axis reorientation is always based on circumferential heterogeneity in cambial region (cambial zone, differentiating and maturing zone) activity occurring at 3 distinct structural levels:

- at the macroscopic level, the division and differentiation of the cambial initials is controlled differently between the upper and the lower side of the trunk. This can lead to an eccentric growth that causes the reaction wood side to be often wider than the opposite side (Dadswell and Wardrop 1949; Almeras et al. 2005);

- at the mesoscopic level, proportions of the various cells types (fibres, vessels, ray and axial parenchyma) constituting secondary xylem can vary substantially between normal and reaction wood (Onaka 1949; Jourez et al. 2001; Ruelle et al. 2006); - at the microscopic level, fibres produced during the reaction process strongly differ structurally from normal fibres. This occurs through the modulation of various structural features: (i) secondary wall fibre thickness, that tends to increase in some species (Ruelle et al. 2006); (ii) size and orientation (MFA) of secondary wall cellulose microfibrils: Washusen and Evans (2001) reported an increase of microfibrils size in tension wood and MFA is known to be lower in tension wood and larger (up to $45^{\circ}$ ) in 
compression wood (Timell 1986; Yoshida et al. 2000; Yoshizawa et al. 2000; Barnett

2004; Clair et al. 2006a); (iii) organization and chemical composition of

49 hemicellulose/lignin matrix surrounding cellulose microfibrils (Pilate et al. 2004;

50 Gorshkova and Morvan 2006).

The mechanism allowing reorientation of the axis originates in structural modifications at the cell-wall level. Indeed, these micro-structural modifications induce in wood a spontaneous tendency to strain during its maturation process (Boyd 1977; Yamamoto 1998; Bamber 2001; Yamamoto et al. 2002). The maturation process of cell wall can be subdivided in steps from cell expansion, secondary wall formation and lignification to cell death (Plomion et al. 2001). During this process compression wood tends to swell and tension wood tends to shrink. This tendency is impeded because reaction wood is stuck to the core of old wood, resulting in a state of mechanical stress (compression or tension), called maturation stress. The asymmetry of longitudinal maturation stress around the circumference results in a bending moment generating a

61 change in curvature and thus a reorientation movement (Archer 1986). The efficiency of 62 this mechanism depends on the difference between the force acting on the reaction wood 63 side and the force acting on the opposite side. The magnitude of the force acting on one 64 side is the integral of the product of the area of maturing wood by the magnitude of the maturation stress in wood. The magnitude of maturation stress in wood, in turn, can be viewed as the product of the maturation strain by wood Young's modulus of wood.

67 Finally, Young's modulus can be expressed as the product of wood density by the 68 specific modulus of wood material elasticity (Almeras et al. 2005).

All four of these biomechanical factors, i.e. maturation stress asymmetry and magnitude, Young's modulus of wood and specific modulus of wood material can be controlled through modulations of cambial activity at the above-mentioned levels. 
72 Eccentric growth controls the area of reaction wood and opposite wood. Proportions of each cell type in the xylem partly control the specific modulus of elasticity of wood.

74 Fibre wall thickness controls wood density. Cellulose microfibril geometry and matrix composition partly control specific modulus of elasticity and directly control sign and magnitude of maturation strain (Okuyama et al. 1995; Yamamoto 1998). The mechanical effect of these structural modifications can be predicted by mechanical models acting at different levels. At the macroscopic level, reaction efficiency can be computed using beam theory and the principles of its application to a growing structure (Fournier et al. 1994a). Fournier and coworkers model (1994a) takes into account the effects of eccentric growth, modulus of elasticity and maturation strain (Almeras et al. 2005). At the mesoscopic level, the effect of wood anatomy (i.e. the proportions and organisation of the different cell types) can be predicted by homogenization procedures (Badel 1999). At the microscopic level, cell wall micromechanical models allow to predict wood specific modulus of elasticity and magnitude and sign of maturation strain (Yamamoto et al. 1998; Yamamoto et al. 2002). These models take as input data quantitative information about cell wall organisation at the microscopic and ultra-structural levels, cell wall chemical composition, and timing of cell wall differentiation and lignification. The structure of reaction wood fibres generally differs from that of normal wood fibres. In gymnosperms, compression wood fibres typically have a round shape, 91 intercellular spaces and cracks in the cell wall (Timell 1986). Their wall is thick and 92 heavily lignified, and the microfibrils are oriented at a wide angle with respect to the fibre 93 axis. Among angiosperms, diversity in the form of tension wood fibres has long been 94 recognized (Onaka 1949; Clair et al. 2006b). The most typical form of angiosperm tension wood is characterized by the development of a so-called gelatinous layer (Glayer). The G-layer is essentially made up of highly crystalline cellulose (Norberg and 
97 Meier 1966; Côté et al. 1969), with a very low microfibril angle (Fujita et al. 1974).

98 However, several species do not develop G-fibres, while showing evidence of tension

99 wood production (Fisher and Stevenson 1981; Clair et al. 2006b).

100 During an exploration of biomechanical strategies of tropical rainforest species,

101 trees from Laetia procera species proved to be very efficient in restoring verticality after

102 accidental leaning (Almeras et al. 2005). Moreover, dissymmetry in the magnitude of 103 maturation strain was identified as the leading factor determining efficiency. The 104 maturation strain of tension wood was especially high in this species and tension wood

105 fibres presented a peculiar polylamellated structure. In order to check whether this 106 macroscopic behaviour was related to characteristic structural features, tension wood and

107 opposite wood were investigated using complementary techniques. In this way, optical 108 and electronic microscopy, histo-chemical reaction and UV microspectrophotometry 109 allowed us to obtain quantitative measurement about the structure and qualitative and 110 semi-quantitative information about the chemical composition of the secondary wall and 111 of the fibres.

\section{MATERIAL AND METHODS}

\section{Plant material and sampling}

114 Laetia procera (Poepp.) Eichler (Flacourtiaceae) is rare to locally frequent in primary and

115 secondary neo-tropical forests, on sandy soil.

116 Five trees were selected in the same area in French Guyana, near Kourou. Their

117 diameter at breast height (DBH) ranged between 19 and $28 \mathrm{~cm}$ (Table 1).

118 All trees were chosen because they were exhibiting a reorientation process after 119 some accidental inclination. This was verified in situ by mechanical estimation of growth 120 strain (GS). Experimentally, maturation strain can be estimated by releasing the 
121 longitudinal stress at the surface of wood and measuring the resulting strain, referred to

122 as residual growth strain (GS). Growth strain is the sum of the maturation and support

123 strains. At the periphery of the trunk, where measurements where done, support strain are

124 due to the support of the newly formed layer and so are close to zero. Thus, growth strain

125 (GS) is very close to maturation strain. In the following text we will use GS, since it is 126 what has been experimentally measured.

127 GS were evaluated using the "single hole" method (Fournier et al. 1994b; Clair et 128 al. 2003; Almeras et al. 2005). This method gives the value of the displacement between 129 two pins, hammered onto the trunk (after local debarking) at a $45 \mathrm{~mm}$ distance from each 130 other. A $20 \mathrm{~mm}$-deep, $20 \mathrm{~mm}$-wide hole is drilled at the mid-point between the two pins. A 131 displacement is measured (in $\mu \mathrm{m}$ ) and converted into a strain (in \%) using a calibration 132 factor: $9.6 \times 10^{-4}$ corresponding to a calibration made on Eperua Falcata (Fournier et al. 133 1994b), a tropical hardwood species with properties similar to those of Laetia procera.

134 Eight measurements (equally spaced around the circumference, i.e. every $45^{\circ}$ ) 135 were performed at breast height on each tree. The first measurement position was located 136 on the upper side of the leaning trunk. Two wood samples were taken, above and below

137 the holes resulting from the measurement method, for anatomical and structural studies. 138 Observations were made on both samples to ensure homogeneity of the studied wood 139 (Fig. 1).

\section{Methods}

141 First, classical optical microscopy on stained sections (including Wiesner reaction) was

142 used for all the 5 trees, in order to check if there were main differences between trees or 143 if the variation varied from one tree to another. Then, other techniques (Scanning

144 Electron Microscopy, UV microspectrophotometry) were only applied to the tree with the 145 highest contrast in GS between upper and lower part, Lp1 (Table 1). 
147 Cross sections (thickness: $24 \mu \mathrm{m}$ ) were made with a sliding microtome using disposable

148 razor blades (Feather N35). Sections were stained with safranin/fast green according to

149 the protocol described by Yoshida et al. (2002). Safranin stains lignified tissues in red

150 and fast green stains both lignified and un-lignified tissues in green.

Wiesner reaction

152 Cross sections (thickness: $12 \mu \mathrm{m}$ ) were made on opposite and tension wood specimens.

153 Wiesner reaction was performed on these sections by pouring a few drops of $2 \%$ 154 phloroglucinol ethanol solution on the section mounted on a glass-slide, adding one drop of $35 \% \mathrm{HCl}$ and covering the section with a cover slip.

156 The Wiesner reactive reacts with coniferyl $(\mathrm{G})$ and synapyl (S) aldehyde units in

157 lignin. The higher the Klason-lignin content the stronger the intensity of the red 158 coloration (Yoshizawa et al. 2000). This result provide us to do a comparison between 159 samples, i.e. a semi-quantitative analysis. As the coloration is not permanent, observation was performed during the 20 minutes after the beginning of the reaction.

162 After dehydration through a graded ethanol series, the sections were embedded in epoxy resin. Thin cross sections (thickness: $1 \mu \mathrm{m}$ ) were cut with a diamond knife, mounted on

164 quartz microscope slides, overlaid with a drop of non-UV-absorbing glycerin, and 165 covered with a quartz cover slip (Okuyama et al. 1998). The sections were observed 166 under a microspectrophotometer (Zeiss MPM800). The scanning range of the wavelength 167 was $250-350 \mathrm{~nm}$, the step of the wavelength scanning was $1 \mathrm{~nm}$, and the bandwidth was 168 adjusted to $5 \mathrm{~nm}$. UV absorption spectra were obtained at various locations inside the 169 secondary wall of opposite and tension wood fibres using a beam spot of $0.5 \mu \mathrm{m}$ 
170 diameter. The absorption spectra directly provide information on cell wall lignin content

171 (Okuyama et al. 1998; Gindl 2002; Yoshida et al. 2002); the higher the absorption, the

172 more lignified the wall. Results from this technique can be used to make a comparison

173 between specimen; ie a semi-quantitative analysis among samples.

174 Each measurement for one position (one part of fibre wall) was repeted 8 times.

175 For each specimen the absorption spectrum of the secondary wall was taken at least on 5

176 different fibres and averaged to determine the UV absorption spectrum of the specimen.

177 The microspectrophotometer settings were: objective lens magnification: $\times 100$; program:

178 Lambdascan; (for more detailed information see Okuyama et al. 1998).

\section{Field-Emission Scanning Electron Microscopy (FE-SEM)}

180 Observations were made in both transverse and longitudinal planes. Sample geometries

181 were $7 \times 5 \times 1 \mathrm{~mm}^{3}$ and $5 \times 1 \times 7 \mathrm{~mm}^{3}$, respectively $(\mathrm{R} \times \mathrm{T} \times \mathrm{L})$. Samples were dehydrated

182 through a graded ethanol series and then processed using the $t$-butanol freeze-drying

183 method. In order to observe cellulose microfibrils of lignified layers, a lignin extraction

184 treatment $\left(\mathrm{NaCl} 0.6 \%, \mathrm{CH}_{3} \mathrm{COOH} 0.13 \%\right.$ in distilled water during 40 hours $)$ was

185 performed on longitudinal sections. The dried samples were mounted on aluminium stubs

186 and lightly sputter-coated with platinum. Samples were observed by FE-SEM (Hitachi, S-

$1874500)$ at an accelerating voltage of $3 \mathrm{kV}$.

188 Microfibril angle (MFA) and diameter of cellulose aggregates were measured

189 from direct observations by SEM on samples from tree Lp1. These measurements were

190 made on 10 pictures per sample with magnifications from $\times 30 \mathrm{k}$ to $\times 70 \mathrm{k}$ and on about

19120 microfibrils per picture for MFA and on 10 areas of about $5000 \mathrm{~nm}^{2}$ for the diameter

192 of cellulose aggregates. Examples of images used for these measurements are shown in

193 Fig. 2. 
195 Results from MFA and cellulose aggregates measurements were compared to highlight

196 significant differences between tension and opposite wood samples. We used the bilateral

197 Student test to account for the significance of these results.

\section{RESULTS}

\section{Growth strain measurements}

200 Measurements clearly show that wood located on the upper side exhibits much higher 201 tensile growth strains than wood located in all other position (Table 1). Measurements performed on the lower (opposite) side do not present significant difference in mechanical stressing with lateral position. Upper wood layer positions with very high growth strains are called tension wood (TW) in the next paragraphs while other positions are named opposite wood (OW) or lateral wood.

Considering data reported by Archer (1986) and more recent studies (Yoshida et

207 al. 2000; Yoshizawa et al. 2000; Clair et al. 2006b), GS observed in tension wood are in 208 the upper range of reported values.

209 Structure of the fibre wall

211 Optical microscopy observations after safranin/fast green staining show a homogeneous

212 typical secondary wall in opposite wood fibres, while a peculiar polylaminate secondary

213 wall structure is observed in tension wood fibres (Fig. 3). This structure consists of an

214 alternance of thick and thin layers. This peculiar secondary wall stains as a typical

215 gelatinous layer (G-layer), i.e. in green without any touch of red as in Populus

216 euramericana (Jourez et al. 2001) or Eperua falcata (Satiat-Jeunemaitre 1986). 
218 Microscopy (SEM) confirms that the polylaminate structure of the secondary wall occurs

219 in tension wood but not in lateral or opposite wood fibres (Fig. 4 and 5). The number of

220 thin layers has been counted on tension wood specimens; results are given in Table 2.

221 There was an average of 5 to 6 thin layers with thick layers between them. Thick layers

222 are approximately ten times thicker than thin layers (Table 2).

Inner thin layer

224 Observations of longitudinal sections (Fig. 6a) also show a lignified layer inside the

225 lumen of tension wood fibres; this inner layer allowed us to prospect the nature and the

226 structure of thin layers observed in the polylaminate secondary wall. The aspect of this

227 layer before (Fig. 6b) and after (Fig. 6c) lignin extraction treatment highlights its lignified

228 feature and its large MFA. These features are typical of the $\mathrm{S}_{3}$ layer commonly observed

229 in the cell wall of opposite wood fibres (Fig. 7a).

231 MFA was very low (close to fibre axis) in the thick layers of tension wood fibres and

232 more than three fold larger $\left(15\right.$ to $\left.20^{\circ}\right)$ in opposite wood $(\mathrm{p}<0.001)$ (Table 3$)$.

233 Unfortunately we were unable to accurately measure MFA in intermediate thin layer.

234 Diameter of cellulose aggregates is in the range of values reported by Fahlen and

235 Salmen (2003) on Picea abies, i.e. between 18 and $23 \mathrm{~nm}$, and is lower in opposite wood $236(\mathrm{p}<0.001)$ than in tension wood, respectively 18.4 and $21.9 \mathrm{~nm}$. 
239 Intensity of the Wiesner reaction gives qualitative information on cell wall lignification

240 features. Polylaminate tension wood fibres appear less lignified than opposite wood fibres

241 (Fig. 8). In TW fibres the reaction is stronger in the outer part and becomes weaker

242 towards the centre. Some TW fibres have stronger reaction intensity than others; some of

243 them even show a lack of reaction on the polylaminate structure although the $\mathrm{S}_{1}$ layer and

244 the primary wall are stained in red by the reaction (Fig. 9). This could mean that various

245 types of tension wood fibres can be observed.

246 Compared to typical G-layers, known to have very low lignin contents, the

247 secondary wall of Laetia TW presents lignin within the thick layers and the coloration 248 inside thin ones indicates a higher amount inside them.

\section{UV microspectrophotometry}

250 The average absorption spectra for the $S_{2}$ layer of a opposite wood sample (Lp1-5) and

251 for thick and thin layers of the secondary wall of a tension wood specimen (Lp1-2) are 252 given in Fig. 10.

In tension wood, the average absorption, and therefore polylaminate layer lignin

254 content, is lower than in the $\mathrm{S}_{2}$ layer of opposite wood. Actually absorbance values in 255 tension wood specimen ranges from 0.15 to 0.24 at $280 \mathrm{~nm}$ and from 0.14 to 0.22 at 270

$256 \mathrm{~nm}$. In opposite wood absorbance values are higher than in tension wood and ranges from

2570.34 to 0.53 at $280 \mathrm{~nm}$ and from 0.31 to 0.47 at $270 \mathrm{~nm}$. Moreover the average absorption 258 of the whole fibre at 270 and $280 \mathrm{~nm}$ decreases with increasing growth strain values 259 (Table 4 and fig. 11). 
UV microspectrophotometry also shows that lignification of TW is stronger in secondary wall thin layers than in the thick layer. Thus, intermediate thin layers are chemically different.

The absorption ratio $\mathrm{A}_{280} / \mathrm{A}_{260}$ markedly depends on the ratio of syringylpropane

264 (S) to guaiacylpropane (G) units. Actually the decrease of this ratio corresponds to an 265 increasing S/G ratio (Okuyama et al. 1998; Yoshida et al. 2002). This ratio for tension wood specimens is largely dominated by the properties of thick layers, because of the prominent proportion of these layers compared to thin layers. According to our results, S/G ratio increases with growth strains, with a good relationship (Table 4 and Fig. 12). This evolution has been also described in some other species differentiating or not a G-

270 layer in their tension wood, such as eucalyptus (Baillères et al. 1995) or Liriodendron 271 tulipifera (Yoshida et al. 2002).

\section{DISCUSSION}

273 Observations made on Laetia procera tension wood show a polylaminate structure of the

274 secondary wall with the alternance of lightly lignified thick layers, with microfibrils 275 almost aligned to the cell main axis, and more lignified thin layers in which it was not 276 possible to measure microfibrils orientation. This kind of polylaminate structure has 277 previously been observed in bamboo cells (Parameswaran and Liese 1976). In a recent 278 study screening the anatomical diversity of tension wood among tropical dicotyledonous 279 species (Clair et al. 2006b), similar features were observed in tension wood of an other 280 Flacourtiaceae, Casearia javitensis. Moreover Daniel and Nilsson (1996) observed this 281 structure in a species from the Flacourtiaceae family, Homalium foetidum, but in their study its occurrence was not identified as a tension wood feature. Observation of this 
peculiar structure in tension wood fibres emphasises the idea exposed in Clair et al.

284 (2006b) on the difficulty to classify tension wood structures.

The very low MFA observed in thick layers is similar to what is usually observed in tension wood fibres, with or without G-layer (Norberg and Meier 1966; Chaffey 2000; Ruelle et al. 2006). The microfibrils of the inner thin layer of these cells appear less organised and lie at a larger angle than those of thick layers. In their study on Homalium foetidum, Daniel and Nilsson (1996) observed differences in microfibril angle between thick and thin layers. These various observations lead us to hypothesise that cellulose organisation in the thin layers is (i) different from the one of thick layers and (ii) similar to the one observed in the inner thin layer, so that all these thin layers look like successive $\mathrm{S}_{3}$ layers between thick layers.

Prodhan et al. (1995) shows that G-layer in Fraxinus mandshurica is lignified, in the same way as in Laetia procera, with a higher content of lignin in the outer part of the G-layer. Similar observations were made by Gierlinger and Schwanninger (2006), i.e. a higher lignification in the outer part of G layer, but in their work they found a very weak content of lignin in the rest of the G layer. These observations support the statement

299 (Terashima 1990) that there is a lignification gradient from outer to inner part of the cell wall during fibre development. However the alternance of more lignified layers raises several questions about the development of the secondary wall and about its role in the very efficient strategy of reorientation observed in this species. In current fibre mechanics models, maturation strain associated to the end of the lignification process is assumed to

304 occur simultaneously in the whole $S_{2}$ or G-layer. Moreover, it is known that the final prestressing values in a multilayered composite depend on the history of layer deposition

306 (Yamamoto et al. 2002). This effect of successive step construction in a material on field 307 of stresses is also true for various natural or man-made structures such as trees, bridges, 
etc. (Guitard et al. 1999; Malzbender 2004).It may be important to know whether each

309 thick layer and associated thin layer is fully lignified successively or if the lignification

310 process occurs after the deposition of all the layers.

311 This raises questions about the rythm of secondary wall development. Hosoo et al.

$312(2002 ; 2003)$ showed diurnal periodicity in the deposition of cell wall components on the

313 innermost surface of developing cells. This seems to indicate that there is diurnal

314 periodicity in cell wall formation, corresponding to the 24-h light-dark cycle. Question

315 about relation between thick and thin layers alternance and circadian rythm should be

316 investigated, and young trees artificially inclined in controlled conditions can be a good

317 material for such study, knowing that tension wood will be rapidly induced on upper part

318 of the young tree (Jourez et al. 2001).

319 The multilayered tension wood has been, until now, only found in others genus of 320 the Flacourtiaceae Family (Daniel and Nilsson 1996; Clair et al. 2006b). It should be 321 interesting to investigate whether this feature occurs in the whole family.

\section{ACKNOWLEDGMENTS}

Many thanks to Tancrède Almeras for his critical review of this paper and Ivan Scotti for English corrections.

\section{REFERENCES}

Almeras T, Thibaut A, Gril J (2005) Effect of circumferential heterogeneity of wood maturation strain, modulus of elasticity and radial growth on the regulation of stem orientation in trees. Trees 19:457-467

Archer RR (1986) Growth stresses and strains in trees. Springer-Verlag, Berlin Heidelberg New-York 
Badel E (1999) Détermination des propriétés élastiques et du retrait d'un cerne annuel de chêne dans le plan transverse : description de la morphologie, mesures des propriétés microscopiques et calculs d'homogénisation

Baillères H, Chanson B, Fournier M, Tollier MT , Monties B (1995) Structure, composition chimique et retraits de maturation du bois chez les clones d'eucalyptus. Ann Sci For 52:157-172

Bamber R (2001) A general theory for the origin of growth stresses in reaction wood : how trees stay upright. IAWA J 22:205-212

Barnett JR (2004) Cellulose microfibril angle in the cell wall of wood fibres. Biol Rev 79:461-472

Boyd JD (1977) Basic cause of differentiation of tension wood and compression wood. Aust For Res 7:121-143

Chaffey N (2000) Microfibril orientation in wood cells : new angles on an old topic. Trends Plant Sci 5:360-362

Clair B, Almeras T, Sugiyama J (2006a) Compression stress in opposite wood of angiosperms: observations in chestnut, mani and poplar. Ann. For. Sci. 63:507-510

Clair B, Ruelle J, Beauchêne J, Prevost MF , Fournier M (2006b) Tension wood and opposite wood in 21 tropical rainforest species. 1. About the presence of G layer. IAWA J 27:329-338

Clair B, Ruelle J , Thibaut B (2003) Relationship between growth stresses, mechanophysical properties and proportion of fibre with gelatinous layer in chestnut (Castanea Sativa Mill.). Holzforschung 57:189-195

Côté WAJ, Day AC, Timell TE (1969) A contribution to the ultrastructure of tension wood fibers. Wood Sci Technol 3:257-271

Dadswell HE , Wardrop AB (1949) What is reaction wood? Australian Forestry 13:22-33

Daniel G , Nilsson T (1996) Polylaminate concentric cell wall layering in fibres of Homalium foetidum and its effect on degradation by microfungi. Recent Advances in WOOD ANATOMY, New Zealand Forest Research Institute:369-372

Fahlen J , Salmen L (2003) Cross-sectional structure of the secondary wall of wood fibers as affected by processing. J Mater Sci 38:119-126

Fisher JB, Stevenson JW (1981) Occurrence of reaction wood in branches of Dicotyledons and its role in tree architecture. Bot Gaz 142:82-95

Fournier M, Baillères H, Chanson B (1994a) Tree biomechanics: growth, cumulative prestress, and reorientations. Biomimetics 2:229-251

Fournier M, Chanson B, Thibaut B , Guitard D (1994b) Mesure des déformations résiduelles de croissance à la surface des arbres, en relation avec leur morphologie. Observation sur différentes espèces. Ann Sci for 51:249-266 
Fujita M, Saiki H, Harada H (1974) Electron Microscopy of Microtubules and Cellulose Microfibrils in Secondary Wall Formation of Poplar Tension Wood Fibers. Mokuzai Gakkaishi 20:147-156

Gierlinger N, Schwanninger M (2006) Chemical Imaging of Poplar Wood Cell Walls by Confocal Raman Microscopy. Plant Physiol 140:1246-1254

Gindl W (2002) Comparing Mechanical properties of normal and compression wood in Norway Spruce: the role of lignin in compression parallel to the grain. Holzforschung $56: 395-401$

Gorshkova T, Morvan C (2006) Secondary cell-wall assembly in flax phloem fibres: role of galactans. Planta 223:149-158

Guitard D, Masse M, Yamamoto H, Okuyama T (1999) Growth stress generation: a new mechanical model of the dimensional change of wood cells during maturation. $\mathrm{J}$ Wood Sci 45:384-391

Hosoo Y, Yoshida M, Imai T, Okuyama T (2002) Diurnal difference in the amount of immunogold-labeled glucomannans detected with field emission scanning electron microscopy at the innermost surface of developing secondary walls of differentiating conifer tracheids. Planta 215:1006-1012

Hosoo Y, Yoshida M, Imai T , Okuyama T (2003) Diurnal Differences in the Innermost Surface of the S2 Layer in Differentiating Tracheids of Cryptomeria japonica Corresponding to a Light-Dark Cycle. Holzforschung 57:567-573

Jourez B, Riboux A, Leclercq A (2001) Anatomical characteristics of tension wood and opposite wood in young inclined stems of poplar (Populus euramericana cv "Ghoy"). IAWA J 22:133-157

Malzbender J (2004) Mechanical and thermal stresses in multilayered materials. J Appl Phys 95:1780-1782

Norberg PH, Meier H (1966) Physical and chemical properties of the gelatinous layer in tension wood fibres of Aspen (Populus tremula L.). Holzforschung 20:174-178

Okuyama T, Takeda H, Yamamoto H, Yoshida M (1998) Relation between growth stress and lignin concentration in the cell wall: Ultraviolet microscopic spectral analysis. $\mathrm{J}$ Wood Sci 44

Okuyama T, Yoshida M, Yamamoto H (1995) An estimation of the turgor pressure change as one of the factors of growth stress generation in cell walls. Mokuzai Gakkaishi 41:1070-1078

Onaka F (1949) Studies on compression and tension wood. Wood research, Bulletin of the Wood research Institute, Kyoto University, Japan 24:1-88

Parameswaran N, Liese W (1976) On the Fine Structure of Bamboo Fibres. Wood Sci Technol 10:231-246 
Pilate G, Chabbert B, Cathala B, Yoshinaga A, Leple JC, Laurans F, Lapierre C, Ruel K (2004) Lignification and tension wood. C R Biologies 327:889-901

Plomion C, Leprovost G, Stokes A (2001) Wood formation in Trees. Plant Physiol $127: 1513-1523$

Prodhan AKMA, Ohtani J, Funada R, Abe H, Fukazawa K (1995) Ultrastructure investigation of tension wood fibre in Fraxinus mandshurica Rupr. var. japonica Maxim. Ann Botany 75:311-317

Ruelle J, Clair B, Beauchêne J, Prevost MF , Fournier M (2006) Tension wood and opposite wood in 21 tropical rainforest species. 2. Comparison of some anatomical criteria. IAWA J 27:341-376

Satiat-Jeunemaitre B (1986) Cell wall morphogenesis and structure in tropical tension wood. IAWA Bull. 7:155-164

Sinnott EW (1952) Reaction Wood and the Regulation of Tree Form. Am J Bot 39:69-78

Terashima N (1990) A new mechanism for formation of a structurally ordered protolignin macromolecule in the cell wall of tree xylem. J Pulp Paper Sci 16:150-155

Timell TE (1986) Compression wood in gymnosperms. Springer-Verlag, Berlin Heidelberg

Washusen R , Evans R (2001) The association between cellulose crystallite width and tension wood occurence in Eucalyptus globulus. IAWA Journal 22:235-243

Yamamoto H (1998) Generation mechanism of growth stresses in wood cell walls : roles of lignin deposition and cellulose microfibril during cell wall maturation. Wood Sci Technol 22

Yamamoto H, Kojima Y, Okuyama T, Abasolo WP, Gril J (2002) Origin of the Biomechanical properties of wood related to the fine structure of the multi-layered cell wall. J Biomech Eng 124:432-440

Yamamoto H, Okuyama T, Yoshida M (1998) Growth stress generation and microfibril angle in reaction wood. Microfibril Angle in Wood. The proceedings of the IAWA / IUFRO international workshop on the Significance of microfibril angle to wood quality:225-239

Yoshida M, Ohta H, Yamamoto H, Okuyama T (2002) Tensile growth stress and lignin distribution in the cell walls of yellow poplar, Liriodendron tulipifera Linn. Trees $16: 457-464$

Yoshida M, Okuda T , Okuyama T (2000) Tension wood and growth stress induced by artificial inclination in Liriodendron tulipifera Linn. and Prunus spachiana Kitamura f. ascendens Kitamura. Ann. For. Sci. 57:739-746

Yoshizawa N, Inami A, Miyake S, Ishiguri F, Yokota S (2000) Anatomy and lignin distribution of reaction wood in two Magnolia species. Wood Sci Technol 34:183196 


\section{FIGURES LEGENDS}

Fig. 1 Localization of specimen used for the experiments

Fig. 2 Example of images used for the measurements of microfibril angle on tension wood (a), opposite wood (b) and cellulose aggregates diameter on tension wood (c), opposite wood (d). Scale bars: $500 \mathrm{~nm}$

Fig. 3 Cross sections of tension wood (a) and opposite wood (b) from Laetia procera stained with safranin/fast green. Scale bars: $25 \mu \mathrm{m}$

Fig. 4 Cross section of tension wood (a) and opposite wood (b) of Laetia procera, observed with SEM. Scale bars: $5 \mu \mathrm{m}$

Fig. 5 SEM observation of the polylaminate structure of the secondary wall in tension wood fibre on a longitudinal section of Laetia procera. Scale bar: $15 \mu \mathrm{m}$

Fig. 6 Longitudinal section of Laetia procera tension wood. (a) Observation of the lignified layer inside the lumen (scale bar: $15 \mu \mathrm{m}$ ). (b) Detail of the image a (scale bar: $1 \mu \mathrm{m}$ ). (c) Detail of the inner layer view from the lumen after a lignin extraction treatment (scale bar: 1 $\mu \mathrm{m})$. Microfibril angle in the inner layer is very large.

Fig. 7 Longitudinal section of Laetia procera opposite wood. (a) Observation of the lignified layer inside the lumen (scale bar: $5 \mu \mathrm{m}$ ). (b) Detail of the image a (scale bar: 1 $\mu \mathrm{m})$. (c) Detail of the inner layer view from the lumen after a lignin extraction treatment (scale bar: $1 \mu \mathrm{m}$ ). Microfibril angle in the inner layer is very large. 
Fig. 8 Result of the Wiesner reaction on transversal sections of tension (a) and opposite (b) specimen of Laetia Procera. Scale bars: $20 \mu \mathrm{m}$

Fig. 9 Detail of a transversal section of tension wood specimen, showing tension wood fibres with lack of Wiesner reaction. Scale bar: $10 \mu \mathrm{m}$

Fig. 10 UV absorption spectra of a tension wood (a) specimen (Lp1-2) and an opposite wood (b) specimen (Lp1-5) of Lp1 tree. Bars are standard deviations

Fig. 11 Absorbance at $280 \mathrm{~nm}$ (a) and $270 \mathrm{~nm}$ (b) versus growth strain values for specimen from Lp1 tree

Fig. 12 Absorbance ratio A280/A260 versus growth strain values of specimen from the tree Lp1 


\section{TABLES}

Table 1 Diameter at breast height (DBH, in cm), Growth Strain (microstrains) means value, standard deviation and number of positions used for upper and lower side for each tree

\begin{tabular}{|c|c|c|c|c|c|c|}
\hline \multirow[b]{2}{*}{ Trees } & \multirow[b]{2}{*}{$\begin{array}{l}\text { DBH } \\
\text { (cm) }\end{array}$} & \multicolumn{2}{|c|}{ Tension wood (TW) } & \multicolumn{2}{|c|}{ Opposite wood (NW) } & \multirow[b]{2}{*}{ Upper - lower side means } \\
\hline & & Mean of the upper side & $\begin{array}{l}\text { Number } \\
\text { of } \\
\text { positions }\end{array}$ & Mean of the lower side & $\begin{array}{l}\text { Number } \\
\text { of } \\
\text { positions }\end{array}$ & \\
\hline Lp1 & 19 & $2714 \pm 700$ & 3 & $666 \pm 293$ & 3 & 2246 \\
\hline Lp2 & 23 & $2035 \pm 625$ & 2 & $515 \pm 23$ & 3 & 1520 \\
\hline Lp3 & 28 & $2701 \pm 318$ & 3 & $666 \pm 247$ & 3 & 2035 \\
\hline Lp4 & 22 & $1590 \pm 681$ & 3 & $582 \pm 105$ & 3 & 1008 \\
\hline Lp5 & 26 & $2912 \pm 404$ & 3 & $416 \pm 200$ & 3 & 2496 \\
\hline
\end{tabular}

Table 2 Values and standard deviation of the various measurements on fibre secondary wall of tension wood specimen from Lp1 tree

\begin{tabular}{|c|c|c|c|c|c|c|c|c|}
\hline \multirow{3}{*}{ Tree } & \multirow{3}{*}{ specimen } & \multirow{3}{*}{ 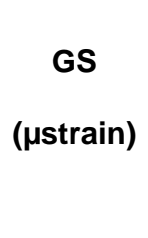 } & \multirow{3}{*}{$\begin{array}{c}\text { Thick layer } \\
\text { thickness }(\mu \mathrm{m})\end{array}$} & \multicolumn{4}{|c|}{ Thin layer } & \multirow{3}{*}{$\begin{array}{l}\text { Thin layer } \\
\text { thickness / thick } \\
\text { layer thickness }\end{array}$} \\
\hline & & & & \multirow{2}{*}{$\begin{array}{c}\text { Thickness } \\
(\mu \mathrm{m})\end{array}$} & \multicolumn{3}{|c|}{ number } & \\
\hline & & & & & $\min$ & mean & $\max$ & \\
\hline \multirow[t]{3}{*}{ Lp1 } & 1 & 3504 & $1.38 \pm 0.26$ & $0.08 \pm 0.03$ & 4 & 5.30 & 8 & 0.06 \\
\hline & 2 & 2170 & $1.31 \pm 0.15$ & $0.13 \pm 0.03$ & 5 & 6.00 & 7 & 0.10 \\
\hline & 3 & 2467 & $1.44 \pm 0.52$ & $0.15 \pm 0.03$ & 4 & 5.13 & 7 & 0.11 \\
\hline
\end{tabular}


Table 3 MFA and diameter of cellulose aggregates (mean \pm SD) for each sample from Lp1 tree. TW: tension wood, OW: opposite wood, LW: lateral wood

\begin{tabular}{|c|c|c|c|c|c|c|c|}
\hline Tree & $\begin{array}{c}\text { Type } \\
\text { of } \\
\text { wood }\end{array}$ & Specimen & $\begin{array}{c}\text { GS } \\
\text { ( } \mu \text { strains) }\end{array}$ & $\begin{array}{c}\text { Average MFA }\left({ }^{\circ}\right) \\
\text { I specimen }\end{array}$ & $\begin{array}{c}\text { Average MFA } \\
\left(^{\circ}\right) \\
\text { / type of wood }\end{array}$ & $\begin{array}{c}\text { Average } \\
\text { diameter of } \\
\text { cellulose } \\
\text { aggregates } \\
(\mathrm{nm}) \\
\text { I specimen }\end{array}$ & $\begin{array}{c}\text { Average } \\
\text { diameter of } \\
\text { cellulose } \\
\text { aggregates } \\
(\mathrm{nm}) / \text { type } \\
\text { of wood }\end{array}$ \\
\hline \multirow[t]{8}{*}{ Lp1 } & TW & 1 & 3504 & $3.1 \pm 1.9$ & & $22.8 \pm 3.0$ & \\
\hline & & 2 & 2170 & $8.6 \pm 5.7$ & $5.2 \pm 3.1$ & $21.7 \pm 2.2$ & $21.9 \pm 0.8$ \\
\hline & & 3 & 2467 & $3.8 \pm 2.3$ & & $21.3 \pm 3.3$ & \\
\hline & LW & 4 & -115 & $16.6 \pm 4.8$ & & $18.3 \pm 1.6$ & \\
\hline & OW & 5 & 346 & $20.7 \pm 5.3$ & & $20.4 \pm 2.2$ & \\
\hline & OW & 6 & 922 & $16.2 \pm 6.2$ & $17.5 \pm 2.8$ & $17.2 \pm 1.9$ & $18.4 \pm 1.6$ \\
\hline & OW & 7 & 730 & $13.9 \pm 4.8$ & & $16.4 \pm 2.1$ & \\
\hline & LW & 8 & 461 & $19.9 \pm 5.2$ & & $19.6 \pm 1.6$ & \\
\hline
\end{tabular}


Table 4 Absorbance at wavelengths 270 and $280 \mathrm{~nm}$ and ratio of absorbance A280/A260 of the various layers of specimen of Laetia procera $\mathrm{n}^{\circ} 1$

\begin{tabular}{|c|c|c|c|c|c|c|c|c|c|}
\hline & Tree & specimen & $\begin{array}{c}\text { GS } \\
\text { ( } \mu \text { strains) }\end{array}$ & & & & & & \\
\hline & & & & \multicolumn{3}{|c|}{ Thick layers } & \multicolumn{3}{|c|}{ Thin layers } \\
\hline & & & & A280 & A270 & A280/A260 & A280 & A270 & A280/A260 \\
\hline Tension & Lp1 & 1 & 3504 & 0.15 & 0.14 & 1.15 & 0.18 & 0.18 & 1.08 \\
\hline wood & & 2 & 2170 & 0.15 & 0.14 & 1.19 & 0.29 & 0.27 & 1.17 \\
\hline \multirow[t]{3}{*}{ specimen } & & 3 & 2467 & 0.24 & 0.22 & 1.20 & 0.38 & 0.36 & 1.13 \\
\hline & & & & \multicolumn{3}{|c|}{$\mathrm{S}_{2}$ layers } & & & \\
\hline & & & & A280 & A270 & A280/A260 & & & \\
\hline Opposite & & 4 & -115 & 0.45 & 0.40 & 1.27 & & & \\
\hline and & & 5 & 346 & 0.44 & 0.40 & 1.31 & & & \\
\hline lateral & & 6 & 922 & 0.37 & 0.33 & 1.25 & & & \\
\hline wood & & 7 & 730 & 0.34 & 0.31 & 1.25 & & & \\
\hline specimen & & 8 & 461 & 0.53 & 0.47 & 1.30 & & & \\
\hline
\end{tabular}




\section{FIGURES}

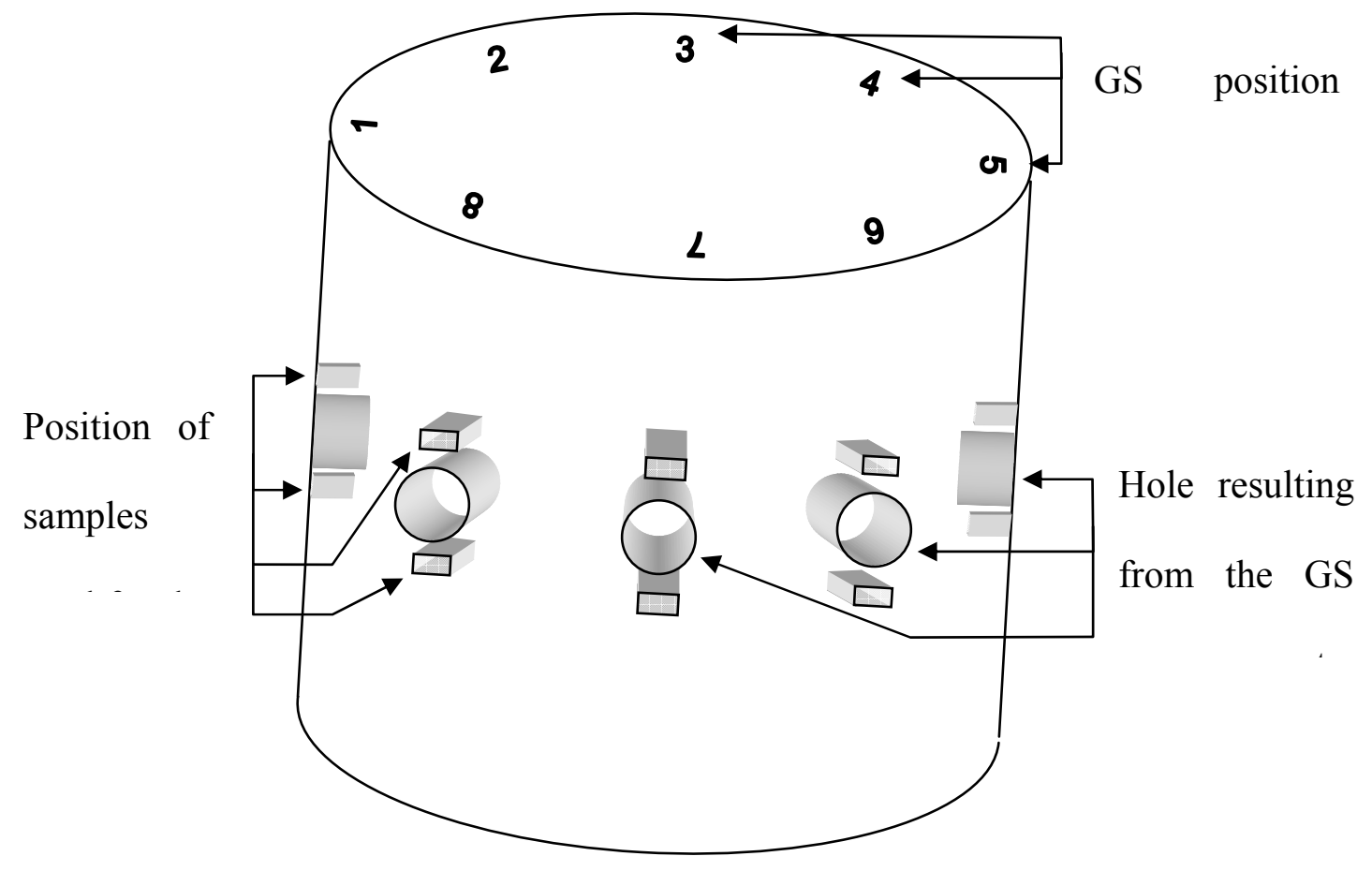

Fig. 1
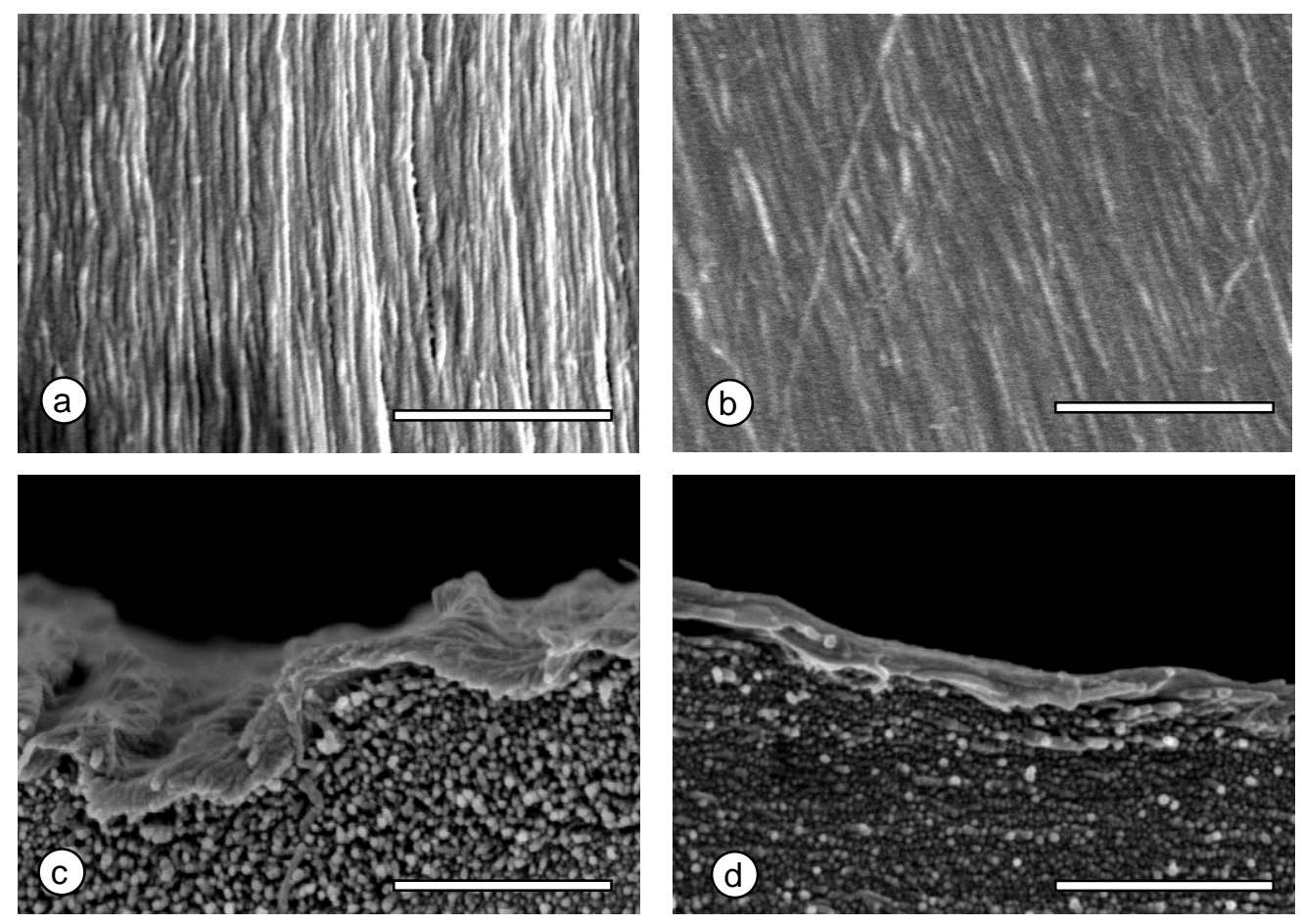

Fig. 2 

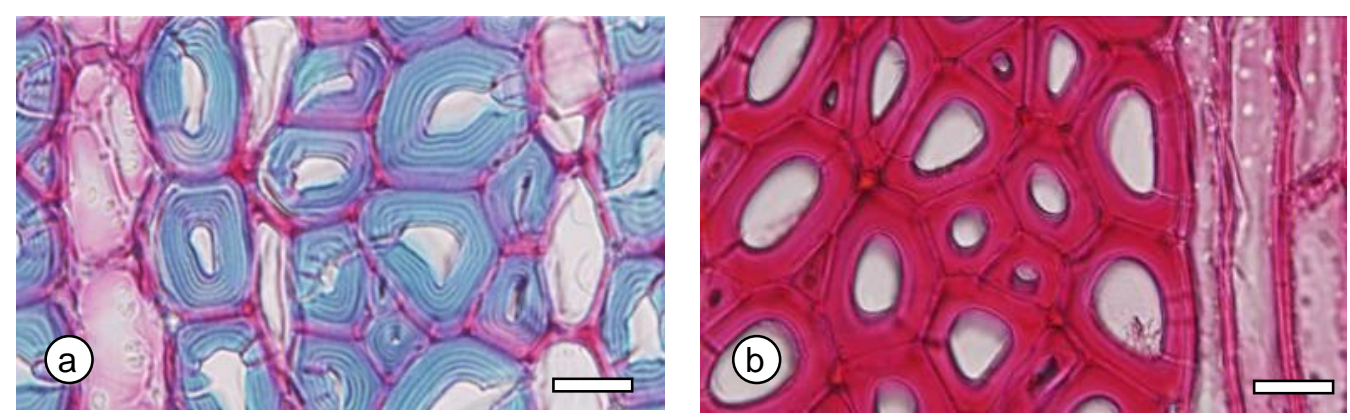

Fig. 3
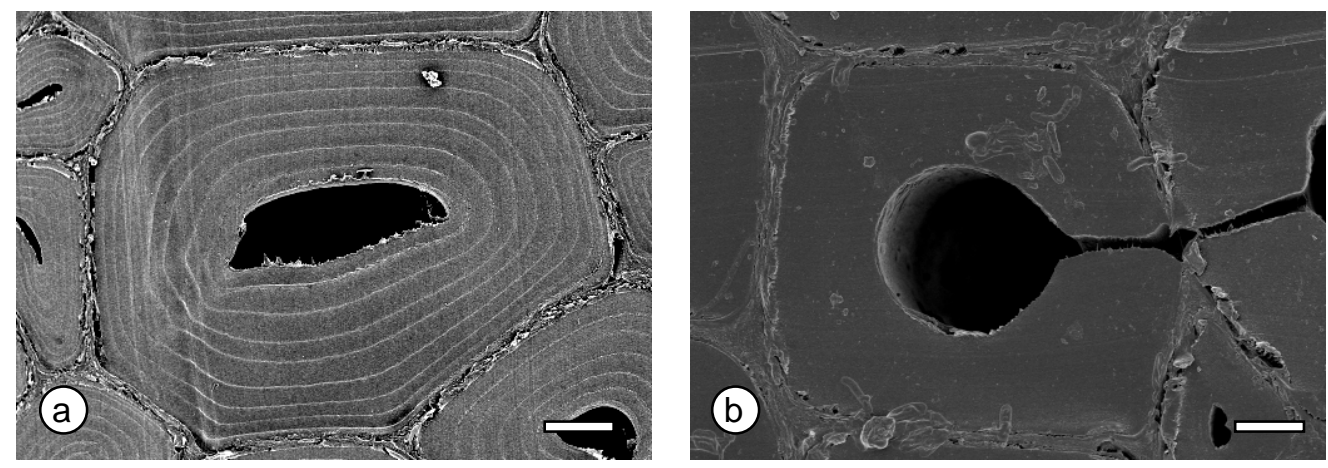

Fig. 4

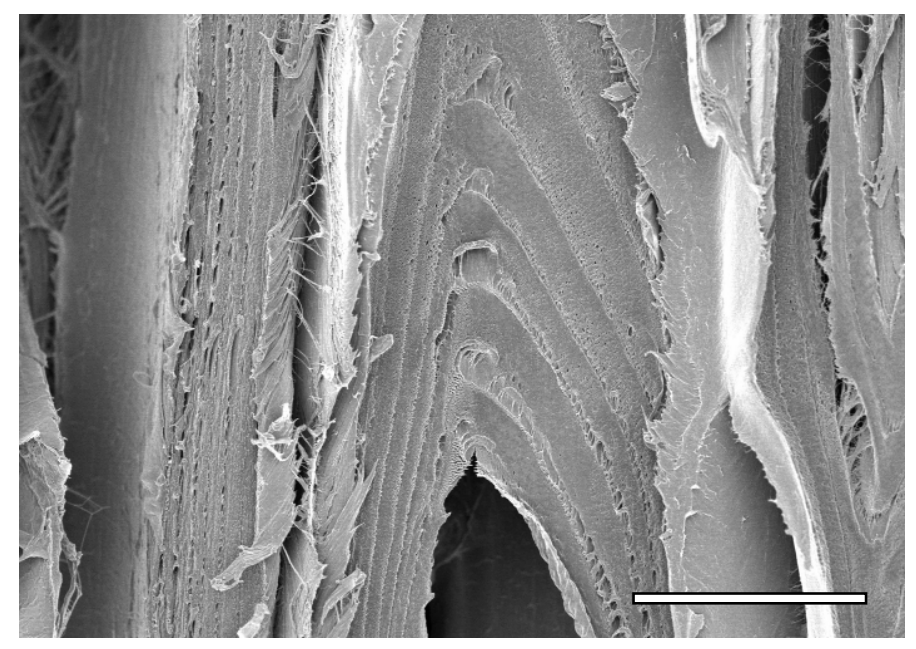

Fig. 5 

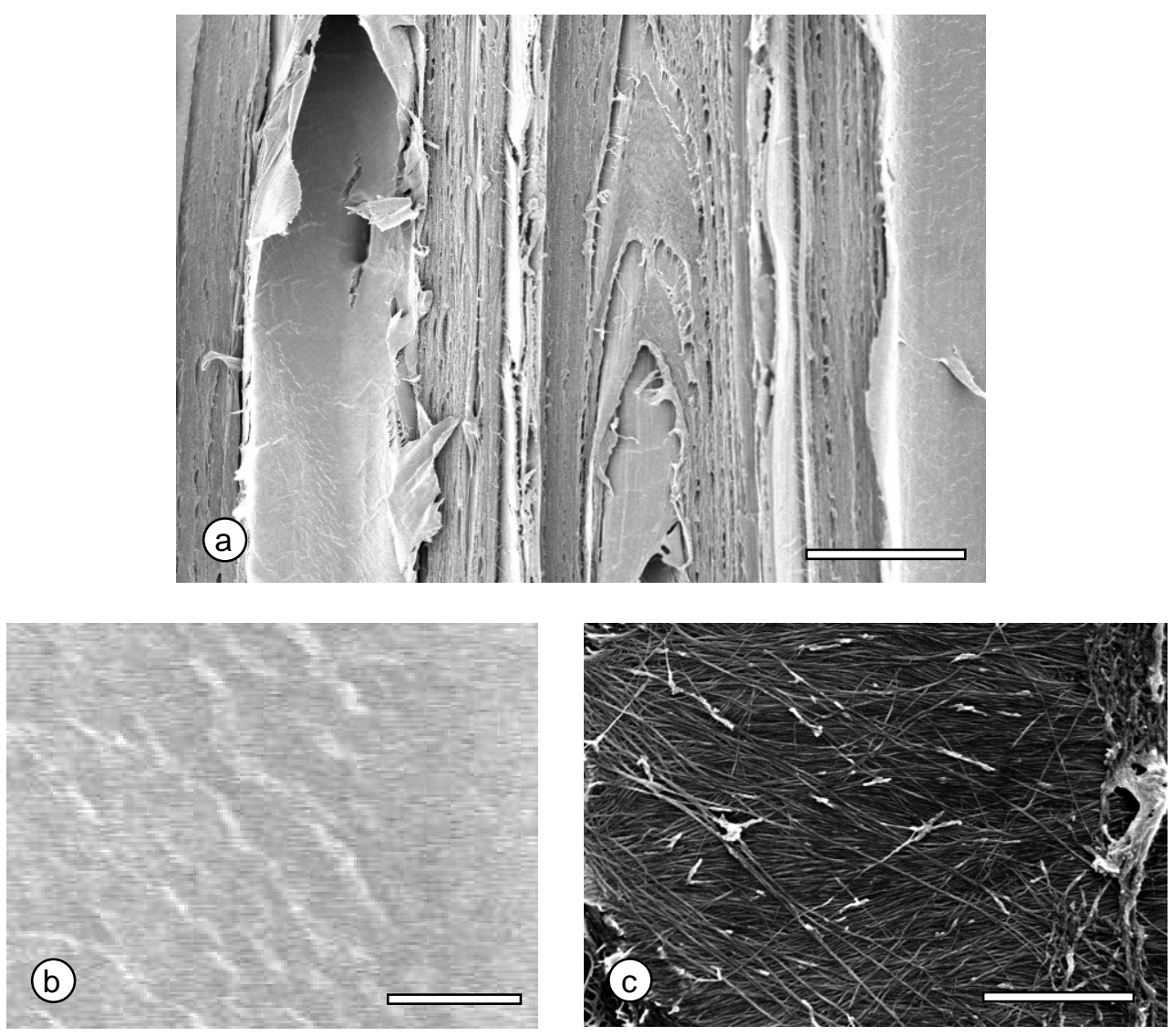

Fig. 6 

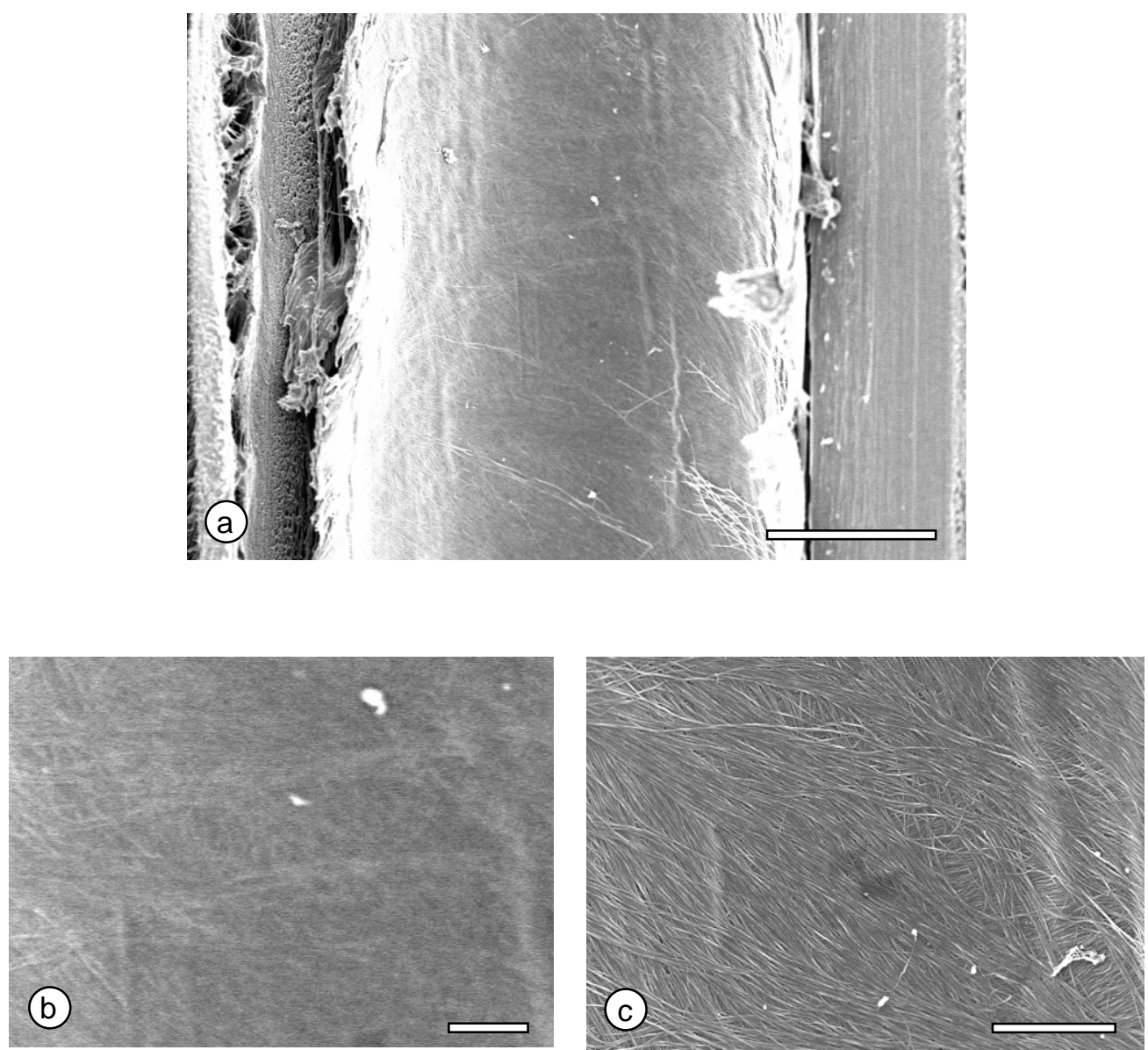

Fig. 7
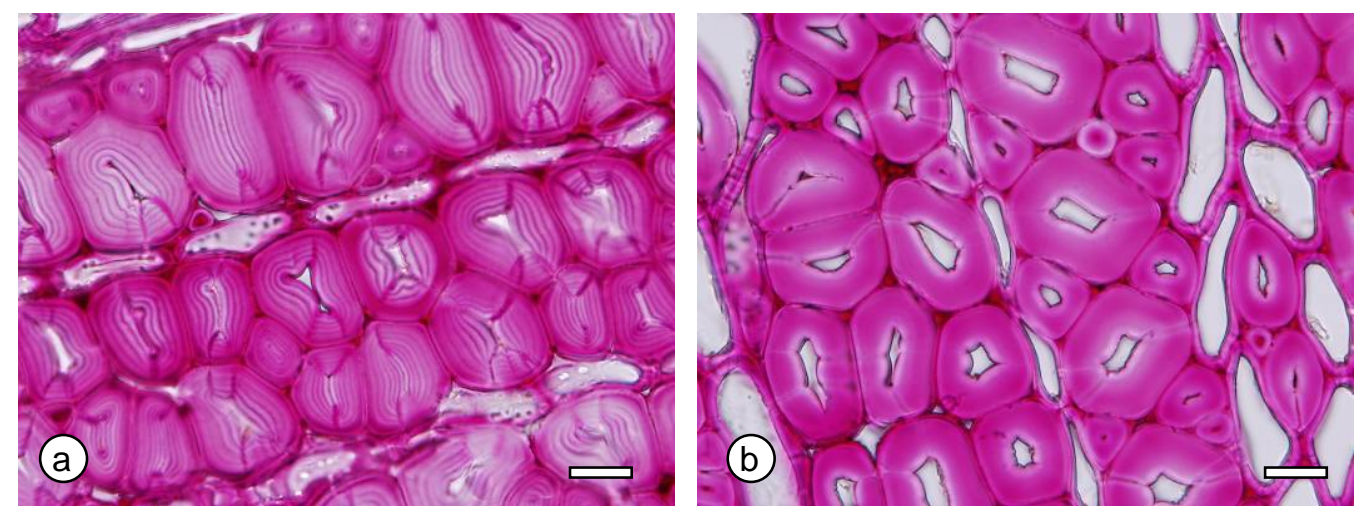

Fig. 8 


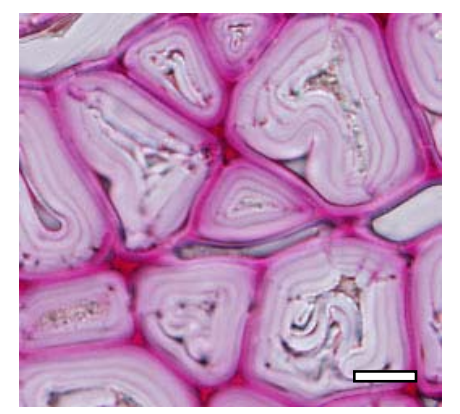

Fig. 9
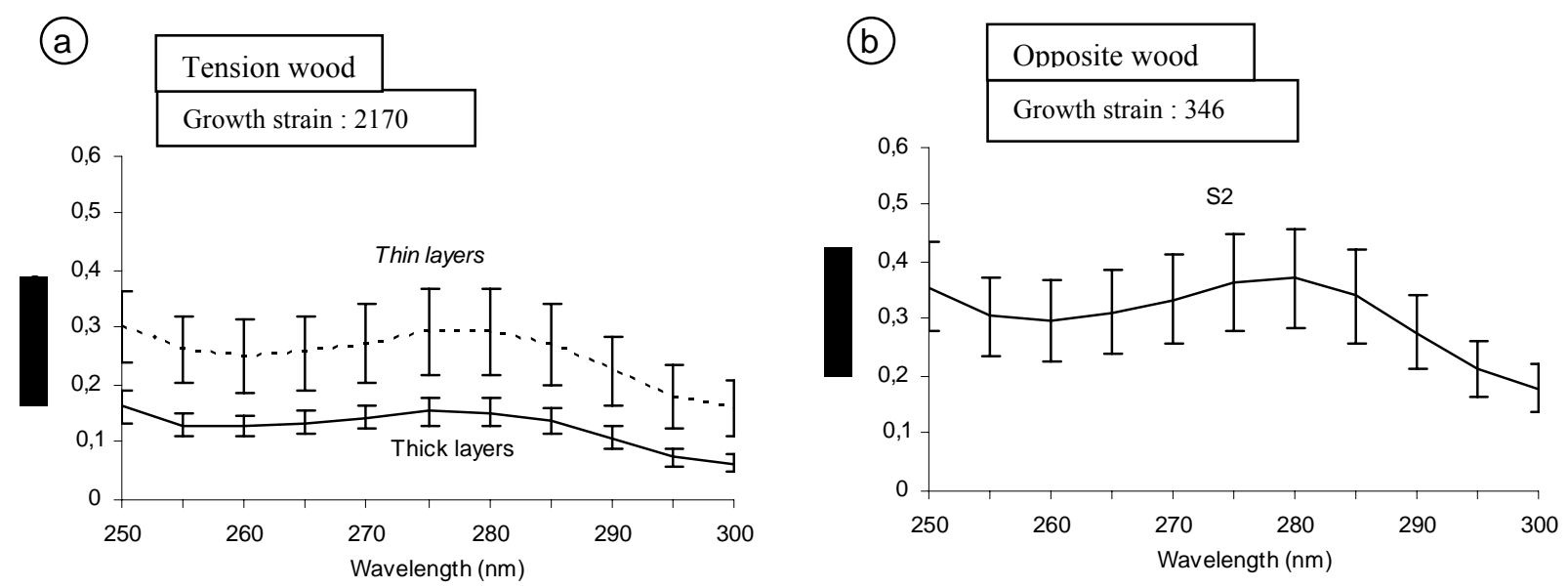

Fig. 10

(a)

(b)
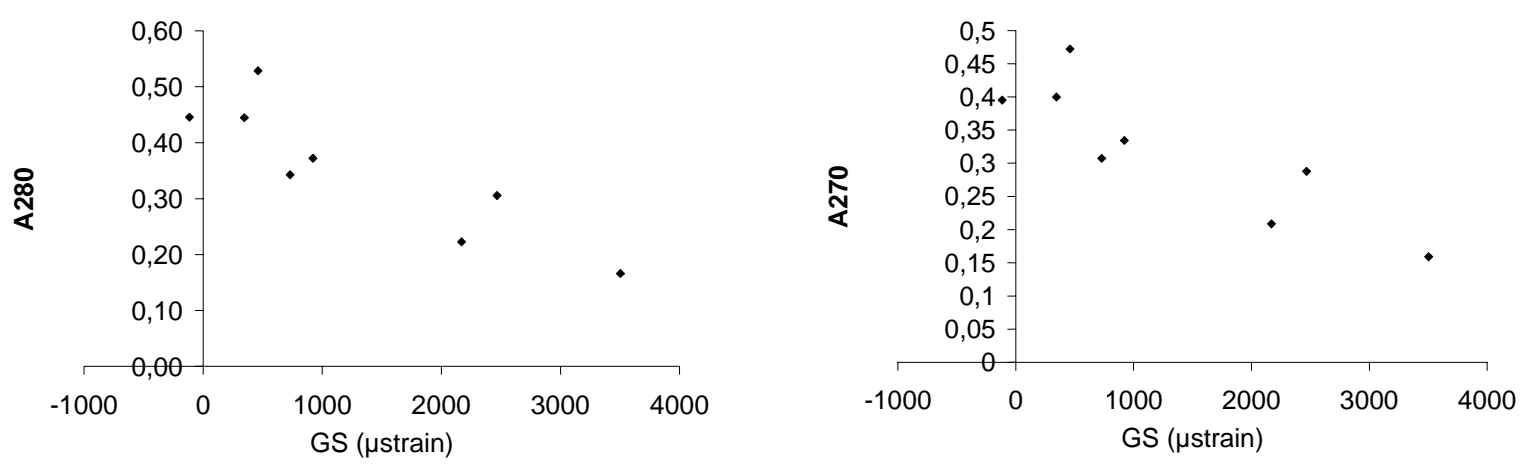

Fig. 11 


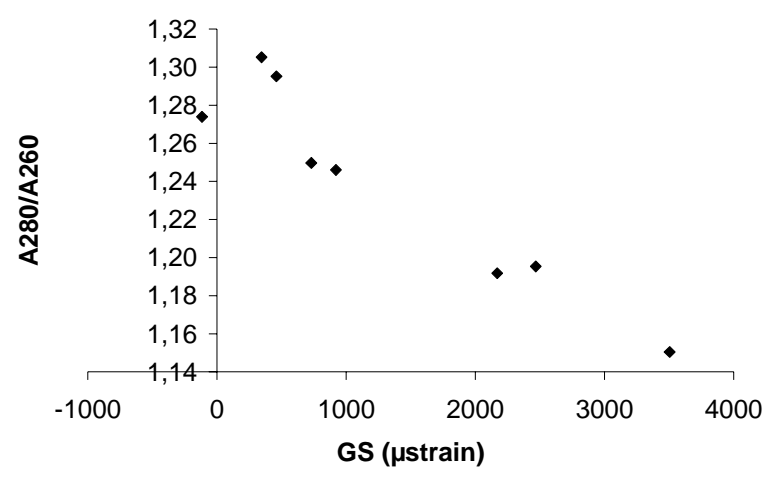

Fig. 12 